The parameters of time and current required to produce ventricular fibrillation have been studied and "earth-leak circuit-breakers" (whose mode of action is described) have been designed to operate within these limits. It was found that in at least 55 out of 62 accidents in which this aspect was studied the return pathway was to earth. If these figures are applied to the whole series it is estimated that about 60 to 70 lives a year might have been saved by the universal installation of these devices (presuming that they fulfilled the theoretical predictions) if they were correctly maintained and adjusted.

This study was made possible by the helpful co-operation of the engineers of the 12 area boards of the Electricity Council and the engineers of the other bodies mentioned. I am indebted to Miss I. Dingwall Fordyce for advice in presenting the data.

\section{Appendix}

In 1963 there were 154 deaths registered the cause of which mentioned electricity. Twelve of these were excluded, as seven of the deaths occurred in 1962 but were not registered until 1963, four victims clearly died from burns, and one died from an explosion. On the other hand, from the sources listed above, nine cases of death from electric shock were not on the Registrar-General's list. This gave a total population of 151, out of which it had been possible to obtain details in 132 cases $(87.5 \%)$ (Table VII).

TABLE VII.-Fatal Electrical Accidents in 1963 Deaths registered, mentioning electricity
Excluded (7 in 1962; burns 4; explosion 1$). . \quad \ldots$ Cases found in survey, not on Registrar-General's list $\begin{array}{llllllr}\text { Total population } & \ldots & \ldots & \ldots & \ldots & \ldots & \overline{151} \\ \text { No details available } & . & \ldots & \ldots & . & \ldots & 19\end{array}$ $\begin{array}{lllllll}\text { Population surveyed } & \ldots & \ldots & \ldots & \ldots & \ldots & \overline{132}\end{array}$
For 1962 the procedure was slightly different. Particulars of 99 electrical fatalities, excluding burns, were collected from the same sources (the 12 area boards, Factory Inspectorate, National Coal Board, and British Railways). The number of deaths registered as accidents caused by electric current in 1962 was 112 (Registrar-General, 1963). Thus details were obtained in $88 \%$ of cases, a proportion very comparable with the proportion for 1963. It is therefore thought justifiable to consider the two years together. Another indication that the sample of records traced for 1962 was representative, for age at least, comes from a comparison of its age distribution with the age distribution of cases recorded by the Registrar-General (Table VIII).

TABle VIII.-Age Distribution of Electrical Fatalities in 1962

\begin{tabular}{|c|c|c|c|c|c|c|c|}
\hline & $0-$ & $5-$ & $15-$ & $45-$ & $65+$ & Unknown & All Ages \\
\hline $\begin{array}{l}\text { From Registrar-General } \\
\% \text { of total } \\
\text { Cases traced }\end{array}$ & $\begin{array}{l}6 \\
5 \\
5\end{array}$ & $\begin{array}{l}16 \\
14 \\
12\end{array}$ & $\begin{array}{l}60 \\
54 \\
54\end{array}$ & $\begin{array}{l}24 \\
21 \\
19\end{array}$ & $\begin{array}{l}6 \\
5 \\
6\end{array}$ & $\frac{-}{3}$ & $\begin{array}{r}112 \\
100 \\
99\end{array}$ \\
\hline
\end{tabular}

\section{REFERENCES}

Dalziel, C. F. (1960). Trans. Amer. Inst. elect. Engrs, 79, 667.

- (1962). Ibid., 81, 978.

Electricity Supply Regulations (1937). H.M.S.O., London.

Ettinger, G. H. (1933). Amer. f. Physiol., 105, 457

- (1935). Ibid.; 111, 406.

erris, L. P., King, B. G., Spence, P. W., and Williems, N. B. (1936). Trans, Amer Inst elect. Engrs, $55,498$.

Jones, H. L. (1895). Brit. med. 买, $1,468$.

Kouwenhoven, W. B., Chesnut, R. W., Knickerbocker, G. G., Milnor, W. R., and Sass, D. J. (1959). Trans. Amer. Inst. elect. Engrs, 78, 163.

Lee, W. R. (1964). Brit. F. Anaesth., 36, 572.

Med Zoledziowski, S. (1964). Brit. $\}$. industr. Med., 21, 135.

Maclachlan, W. (1930). F. industr. Hyg., 12, 291.

Morikawa, S., and Steichen, F. (1960). Anesthesiology, 21, 222

Oliver, T., and Bolam, R. A. (1898). Brit. med. F., 1, 132

Prevost, J. L., and Batelli, F. (1899). F. Physiol. Path. gén. 1' 399427

Registrar-General (1902-64). Statistical Reviers of England and iV ales for the Years 1901-1963. H.M.S.O., London.

Roberts, T. D. M. (1954). Vet. Rec., 66, 561.

Robson, J. G. (1964). Brit. F. Anaesth., 36, 536.

\title{
Vocal Cord Paralysis and Voice Changes in Patients with Surgical Hypoparathyroidism
}

\author{
BRIAN T. SHEARMAN,* M.B., B.S., F.R.A.C.S., D.L.o. ; JOHN S. CLUBB, † M.B., B.S. ; \\ FRANCIS C. NEALE, $\ddagger$ PH.D., F.R.I.C.; SOLOMON POSEN,§ M.B., M.R.C.P., M.R.A.C.P.
}

Brit. med. F., 1965, 2, 619-621

Vocal cord paralysis and hypoparathyroidism are both wellrecognized sequelae of thyroid surgery. Several reported series (Riddell, 1956 ; Wade, 1960 ; Blomstedt and Rydmark, 1960 ; Blackburn and Salmon, 1961) have indicated the prevalence of each complication following different types of thyroid operations. There is, however, little published material concerning their coexistence in the same subject. This paper described the results of indirect laryngoscopy in a group of patients suffering from chronic post-operative hypoparathyroidism.

\section{Patients and Methods}

The group designated "hypoparathyroid" consisted of one man and 25 women aged 29-70 years at the time of examination. In all of them one or more thyroid operations had been performed for various indications, at times ranging from six months to 29 years before this study. They had been referred by a number of physicians and surgeons because of our interest in hypoparathyroidism, and in each patient a serum calcium of $8.5 \mathrm{mg} . / 100 \mathrm{ml}$. or below had been demonstrated on at least one occasion by the method in use at the time of diagnosis (Clark and Collip, 1925 ; Fales, 1953 ; Technicon Corporation, 1960). Patients were not classified as hyopaparathyroid unless at the time of their hypocalcaemia their blood urea nitrogen was 24 mg. $/ 100 \mathrm{ml}$. or less, they had no symptoms of malabsorption, and their serum specific gravity was such that serum calcium, when corrected for serum specific gravity (Dent, 1962), did not exceed $8.5 \mathrm{mg} . / 100 \mathrm{ml}$. Patients in whom serum specific gravity had not been estimated at the time of hypocalcaemia were not included unless their serum calcium was $8 \mathrm{mg} . / 100 \mathrm{ml}$. or

* E.N.T. Registrar, Sydney Hospital.

† Assistant Medical Registrar, Sydney Hospital. Present address : University Depariment of Medicine, St. Vincent's Hospital, Melbourne.

\$ Biochemist, Sydney Hospital. 
less. Manœuvres designed to lower serum calcium (Fourman et al., 1963) were not used. Twenty-four of these patients had had fits, tetany, or both, and at the time of examination all were receiving vitamin-D therapy.

The patients were specifically questioned regarding persistent voice changes dating from the time of operation noted by themselves or their friends. Indirect laryngoscopy was then performed by one of us (B. T. S.) without any knowledge of the patients' parathyroid function. Vocal cord paralysis was said to be present when one or both cords lay in the median or paramedian position (Hagan, 1963) and failed to show intrinsic movement either on inspiration or on phonation. Patients in whom laryngoscopy showed only diminution or asymmetry of cord movement were classified as normal.

The "normocalcaemic" group consisted of 52 patients who had previously undergone subtotal thyroidectomy and whose names had been obtained from the hospital records. These patients were matched with the hypoparathyroid group for ages and dates of operations but were otherwise unselected, except by their attendance in response to a circular letter. No patient in this group was receiving vitamin $\mathrm{D}$, and in each case the serum calcium by the method of Fales (1953) was 8.6 $\mathrm{mg} . / 100 \mathrm{ml}$. or above at the time of this study. These patients were questioned and examined in the same way as the hypoparathyroid subjects.

\section{Results}

The results of our findings are recorded in the Table. Thirteen of the 26 patients in the hypoparathyroid group had vocal cord paralysis, 12 of them with subjective voice changes. In three patients the paralysis was bilateral. Five of the six patients who had had more than one operation showed paralysis of one or both cords. On direct questioning four of the 13 patients in this group without objective laryngeal signs complained of voice changes. The age of the patients and the time interval between operation and this follow-up had no bearing on the incidence of vocal cord paralysis or subjective voice changes.

Laryngeal Examination and Voice Changes in 78 Patients After Thyroidectomy

\begin{tabular}{lc|c|c|c}
\hline & $\begin{array}{c}\text { No. of } \\
\text { Patients }\end{array}$ & $\begin{array}{c}\text { Vocal } \\
\text { Cord } \\
\text { Paralysis }\end{array}$ & $\begin{array}{c}\text { Subjective } \\
\text { Voice Change } \\
\text { Only }\end{array}$ \\
\hline $\begin{array}{l}\text { Hypoparathyroid group } \\
\text { Normocalcaemic group }\end{array}$ & $\cdots$ & 26 & 13 & 4 \\
\hline
\end{tabular}

Of the 52 normocalcaemic patients, four showed unilateral vocal cord paralysis, three of them with subjective voice changes. Of the 48 normocalcaemic patients without cord paralysis, 15 complained of voice changes.

Thus all but 2 of the 17 patients with cord paralysis had laryngeal symptoms. On the other hand, in both groups about one-third of the patients without objective laryngeal signs complained of persistent voice changes dating from the time of the operation. There was no difference between the mean serum calcium of the patients with subjective voice changes and those without symptoms.

The difference in the prevalence of vocal cord paralysis in the two groups is significant at the $0.1 \%$ level.

\section{Discussion}

Since the similar surgical situations are likely to lead to parathyroid and recurrent laryngeal damage, the coexistence of these sequelae was to be expected. Nevertheless, we were able to find only one study in any way comparable to ours. Ranke and Holinger (1955) estimated serum calcium and phosphorus in a group of patients with post-thyroidectomy vocal cord paralysis.
In their series of 100 patients, 16 were found to be "hypoparathyroid," though they did not define " low" serum calcium levels or "high" serum phosphorus levels. It is also not clear from Ranke and Holinger's work whether, in order to be classified as "hypoparathyroid," patients had to show either or both biochemical changes or a combination of clinical and biochemical abnormalifies.

The diagnosis of vocal cord paralysis must necessarily depend on visual inspection. However, we believe that the sign of an immobile cord in the median or paramedian position is sufficiently diagnostic to form the basis of a division into normal and abnormal groups, especially if minor decreases in movement are ignored. Transient vocal cord paralysis, which may occur after thyroid operations (Hawe and Lothian, 1960), was considered unlikely in any of our patients because of the time interval between the operations and the time of study. Only one of our subjects with cord paralysis was examined less than 12 months after the last operation.

The prevalence of vocal cord paralysis in our normocalcaemic group, though apparently high $(7.7 \%$ of patients operated on, or $3.8 \%$ of nerves at risk) is not markedly different from that found in some other series in which all patients were subjected to laryngoscopy regardless of symptoms (Roy et al., 1956 ; Blomstedt, 1959).

It may be objected that our two groups are not strictly comparable and that the hypoparathyroid group may contain an unduly large number of patients who sought or obtained medical attention because of vocal cord paralysis and who were subsequently referred to us. This would imply that numbers of hypoparathyroid subjects are present in the community who are unrecognized because of a lack of laryngeal pathology. This is not borne out by several studies (Thorén and Wijnbladh, 1956 ; Girling and Murley, 1963) in which serum calcium was estimated in large numbers of patients after thyroidectomy, regardless of symptoms, and in which only about $1 \%$ of the subjects were found to be hypocalcaemic.

A further objection may be raised against the arbitrary placement of a patient in one or the other group on the basis of a serum calcium estimation, rather than on the basis of symptoms, such as tetany. We believe that in the final analysis hypoparathyroidism is best defined by reference to an empirically chosen maximum serum calcium concentration. Provided other causes of hypocalcaemia are excluded, a serum calcium of 8.5 $\mathrm{mg} . / 100 \mathrm{ml}$. or below is a better indication of hypoparathyroidism than is the presence of tetany (Schiff, Clubb, Neale, and Posen, in preparation).

The occurrence of laryngeal symptoms in patients without objective signs is well recognized and is believed to follow operative damage to branches of the superior laryngeal nerve (Durham and Harrison, 1964; Reeve, 1964). The high incidence of voice changes in both our groups resembles that found by Borgstrom (1956), and may be related to our mode of interrogating the patients specifically for hoarseness, inability to sing, and weakness of the voice, dating from the time of operation.

When half a group of 26 patients with post-operative hypoparathyroidism are found to have vocal cord paralysis one wonders to what extent "laryngeal stridor" (Albright and Reifenstein, 1948), “laryngospasm" (Buckwalter et al., 1955), and "asthma" (Fourman et al., 1963) are due to recurrent laryngeal-nerve damage. This question is not likely to be answered unless all patients with post-operative hypoparathyroidism are subjected to laryngoscopy.

\section{Summary}

Thirteen of a group of 26 patients with post-operative hypoparathyroidism showed vocal cord paralysis on indirect laryngoscopy, compared with 4 of a group of 52 patients 
who had had a subtotal thyroidectomy but who were normocalcaemic.

In each group about one-third of the patients without objective laryngeal signs complained of persistent voice changes dating from the time of operation.

Our thanks are due to the various physicians and surgeons who referred patients for study. We are grateful to Associate Professor T. S. Reeve for his helpful advice and criticism. Miss Felicity Johnson gave valuable clerical assistance.

This work was supported by the Postgraduate Medical Foundation, University of Sydney, the N.S.W.. State Cancer Council, Messrs. Farmer Hill Pty. Ltd., and Messrs. Geigy (Australasia).

\section{RBFERENCES}

Albright, F., and Reifenstein, E. C. (1948). The Parathyroid Glands and Metabolic Bone Disease. Williams and Wilkins, Baltimore.
Blackburn, G., and Salmon, L. F. W. (1961). Brit. F. Surg., 48, 371. Blomstedt, B. (1959). Acta chir. scand., 118, 97. - and Rydmark, K. E. (1960). Acta oto-laryng. (Stockh.), 52, 150. Borgstrom, S. (1956). Acta ckir. scand., 111, 351.

Buckwalter, J. A., Soper, R. T., Davies, J., and Mason, E. E. (1955).

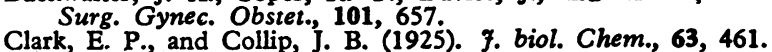

Dent, C. E., (1962). Brit. med. Ұ., 2, 1419.

Durham, C. F., and Harrison, T." S. (1964). Surg. Gynec. Obstet., 118, 38.

Fales, F. W. (1953). 7. biol. Chem., 204, 577.

Fourman, P., Davis, R. H., Jones, K. H., Morgan, D. B., and Smith, J. W. G. (1963). Brit. F. Surg, 50, 608

Girling, J. A., and Murley, R. S. (1963). Brit. med. 7., 1, 1323.

Hagan, P. J. (1963). Ann. Otol. (St. Louis), 72, 206.

Hawe, P., and Lothian, K. R. (1960). Surg. Gynec. Obstet., 110, 488.

Ranke, E. J., and Holinger, P. H. (1955). \$. Amer. med. Ass., 158, 543.

Reeve, T. S. (1964). Paper read at Annual Meeting, Endocrine Society of Australia, Canberra.

Riddell, V. H. (1956). Lancet, 2, 638.

Roy, A. D., Gardiner, R. H., and Niblock, W. M. (1956). Ibid., 1, 988. Technicon Instruments Corporation (1960). Modified Method for Calcium Determination, Chauncey, N.Y.

Thorén, A., and Wi nbladh, H. (1956). Acta endocr. (Kbh.), 22, 224.

Wade, J. S. H. (1960). Brit. F. Surg., 48, 25.

\section{Tissue Concentration of Nalidixic Acid in Chronic Pyelonephritis}

\section{R. M. JAMESON,* F.R.C.S.}

Brit. med. F., 1965, 2, 621-622

Chronic pyelonephritis is as common as ever although chemotherapeutic agents and antibiotics have adequate in vitro bactericidal effects. One probable reason for the failure of such agents to eradicate pyelonephritis is an insufficient concentration of the bactericidal agent in the kidney tissue. The aim of treatment is to eradicate parenchymal and tubular infection as well as to produce sterile urine.

Nalidixic acid (Negram) has been used to treat urinary-tract infections (Lishman and Swinney, 1963; Barlow, 1963; Jameson and Swinney, 1963 ; Ward-McQuaid et al., 1963 ; Swinney, 1964). The results obtained were encouraging and led to the study of the tissue concentration of nalidix acid in the pyelonephritic kidney.

\section{Materials and Methods}

Elective nephrectomy is an accepted procedure in chronic pyelonephritis, and volunteers from the waiting-list for nephrectomy provided the tissue used in this study. In each case the chronic pyelonephritis was associated with stone, hypertension, hydronephrosis, or recurrent infection. All the patients had urinary infections due to Escherichia coli or proteus-type organisms on admission. In every instance the organisms were sensitive to nalidixic acid, and urine cultures were negative on the day of operation and after seven days' treatment. Premedication samples of blood and urine were obtained for control from each volunteer before administration of $1 \mathrm{~g}$. of nalidixic acid six-hourly. At varying time intervals during treatment nephrectomy was performed, and the renal tissue, blood, and urine concentrations of nalidixic acid measured. Samples of renal tissue from four untreated patients were analysed to act as controls for the series.

After nephrectomy an obviously diseased area of the kidney was removed and divided into cortical and medullary blocks each about 1-2 c.cm. in size. These two samples were dried with blotting-paper, placed into clean dry jars, and sent with

\footnotetext{
* Senior Registrar, Department of Urology, Newcastle upon Tyne General Hospital.
}

the blood and urine specimens for analysis. Care was taken that the adjacent tissue was submitted for histological study. The spectrophotofluorimetric technique described (McChesney et al., 1964) measures free and protein-bound nalidixic acid; the biologically inactive metabolites are not determined.

During this investigation the opportunity arose to measure nalidixic acid concentrations in blood, urine, kidney, and pus in a man with externally draining renal suppuration who later underwent nephrectomy.

\section{Results}

All 11 patients had proved chronic pyelonephritis and infections of the urinary tract which responded to treatment with nalidixic acid. The infecting organisms found were: coliform and proteus type in six, coliform in three, and proteus type in two.

The control group of patients who did not receive treatment grew $E$. coli from their urine before nephrectomy. No apparent nalidixic acid was found in the blood, urine, or kidney tissue.

The levels of nalidixic acid in the renal cortex and medulla, blood, and urine after treatment with the drug at the dose of $1 \mathrm{~g}$. six-hourly are shown in Table I. One patient not included

TABLE I.-Levels of Unconjugated Nalidixic Acid in the Renal Cortex

\begin{tabular}{|c|c|c|c|c|c|c|}
\hline \multirow[b]{2}{*}{$\begin{array}{l}\text { Case } \\
\text { No. }\end{array}$} & \multirow[b]{2}{*}{$\begin{array}{c}\text { Days of } \\
\text { Medication } \\
\text { (1 g. } \\
6 \text {-hrly) }\end{array}$} & \multirow[b]{2}{*}{$\begin{array}{l}\text { Plasma } \\
\text { (mg./1.) }\end{array}$} & \multicolumn{3}{|c|}{ Kidney } & \multirow[b]{2}{*}{$\begin{array}{c}\text { Urine } \\
\text { (mg./1.) }\end{array}$} \\
\hline & & & $\begin{array}{c}\text { Cortex } \\
(\mathbf{m g} . / \mathrm{kg} .)\end{array}$ & $\begin{array}{c}\text { Medulla } \\
\text { (mg./kg.) }\end{array}$ & $\begin{array}{c}\text { Average } \\
\text { Renal } \\
\text { Tissue } \\
\text { (mg./kg.) }\end{array}$ & \\
\hline $\begin{array}{r}1 \\
2 \\
3 \\
4 \\
5 \\
6 \\
7 \\
8 \\
9 \\
10 \\
11\end{array}$ & \begin{tabular}{|l|}
1 \\
2 \\
2 \\
3 \\
4 \\
5 \\
6 \\
7 \\
8 \\
6 weeks \\
4 months \\
\end{tabular} & $\begin{array}{c}1 \cdot 8 \\
3.8 \\
2.5 \\
20.5 \\
1 \\
\text { No sample } \\
9 \\
1 \\
30 \\
<1 \\
<1\end{array}$ & $\begin{array}{c}15 \\
8 \\
15 \\
8.5 \\
6.1 \\
3.2 \\
1.8 \\
1.0\end{array}$ & $\begin{array}{r}2 \overline{15} \\
5.7 \\
11.3 \\
10.5 \\
8.8 \\
6.0 \\
4.5 \\
3.8\end{array}$ & $\begin{array}{c}2.2 \\
18 \\
6.9 \\
13.2 \\
5.3 \\
9.5 \\
7.5 \\
4.6 \\
3.7 \\
0.6 \\
2.4\end{array}$ & $\begin{array}{l}123 \\
49 \\
180 \\
174 \\
180 \\
102 \\
89 \\
576 \\
440 \\
130 \\
1\end{array}$ \\
\hline
\end{tabular}

